\title{
THE EFFECT OF AUTOMOTIVE VEHICLE BRAKING SYSTEM FAILURE ON DRIVING SAFETY
}

\author{
Mariusz Kowalski \\ The First Airlift Base \\ Żwirki i Wigury Street 1c, 00-909 Warsaw, Poland \\ tel.: +48226821468 \\ e-mail:mkowalski1102@gmail.com
}

\begin{abstract}
The paper describes systems responsible for driving safety of vehicles weighing up to 3.5 t. It is focused on selected failures (fouling) of braking systems that are typical during motor cars operation. Simulation testing regarding effect of selected failures (fouling) of braking system elements on braking force and braking efficiency were performed. In order to perform such testing, author of the paper worked out the methodology of testing which is also described here. The test results (partial) are displayed as tables and charts. The negative effect of selected failures on braking force and braking efficiency index is influencing directly on motor cars driving safety. It is also emphasized that it is important to maintain and observe automotive manufacturers' technical requirements regarding braking system elements such as tyre pressure, tyre tread condition, brake shoes wear, etc. Basing on the test results it is found that excessive wear of tyres and brake shoes wear could be the reason of significant $W_{S H}$ index decrease resulting in faulty car. This can be visible through lower than allowable level of braking efficiency index WSH, which is the basic legal diagnostic parameter of break system condition assessment. Replacing such elements significantly improves braking efficiency index $W_{S H}$.
\end{abstract}

Keywords: car diagnostics, braking system, driving safety

\section{Introduction}

One of important aspects of our everyday life is possibility to communicate freely using a car. However, from technical point of view, construction of cars should minimize both danger of accident and its possible results. Systems and equipment ensuring safety during car driving develop permanently. All modules responsible for driving safety should be harmonized with each other as much as possible.

The car structure includes systems responsible for driving safety in special way. Such systems are commonly known as "driving safety systems". They are the following:

- braking system, supported with different systems enabling braking force correction, as well as vehicle traction control,

- steering system, enabling safe steerability and proper wheel and road mating,

- suspension system, including elements enabling vehicle movement such as wheels, suspension, frame or integral body,

- lighting systems, useful especially during night driving.

There are also specific systems and equipment significantly lowering an accident risk. They ensure stable and efficient braking, proper acceleration and predictable behaviour on the road, enabling having control of the vehicle in critical situation. The systems are mostly electronic ones that support basic systems of driving safety, involving such elements as sensors, video cameras, microprocessors and the like.

\section{Analysis of selected failures of driving safety systems}

There are many failures regarding driving safety and they were mentioned several times in connection with analysing different events and accidents. However, it is interesting how some 
(selected) braking system failures influence technical condition of car and braking efficiency in unexpected situations.

But this is not the question of failure of important elements of driving safety systems being analysed, and only some (simply connected with use) wear of typical elements of specific systems that usually rather are not taken into consideration during normal use.

According to above mentioned, testing involved use of Korean car Hyunday Accent II - Fig. 1.

The effect of the following factors on car performance was simulated during testing:

- Tyre pressure,

- Tyre wear,

- Vehicle load,

- Brake shoes wear level,

- Condition of surfaces under friction (braking disc and shoes):

- covered (spilled) with water,

- covered (contaminated) with oil.
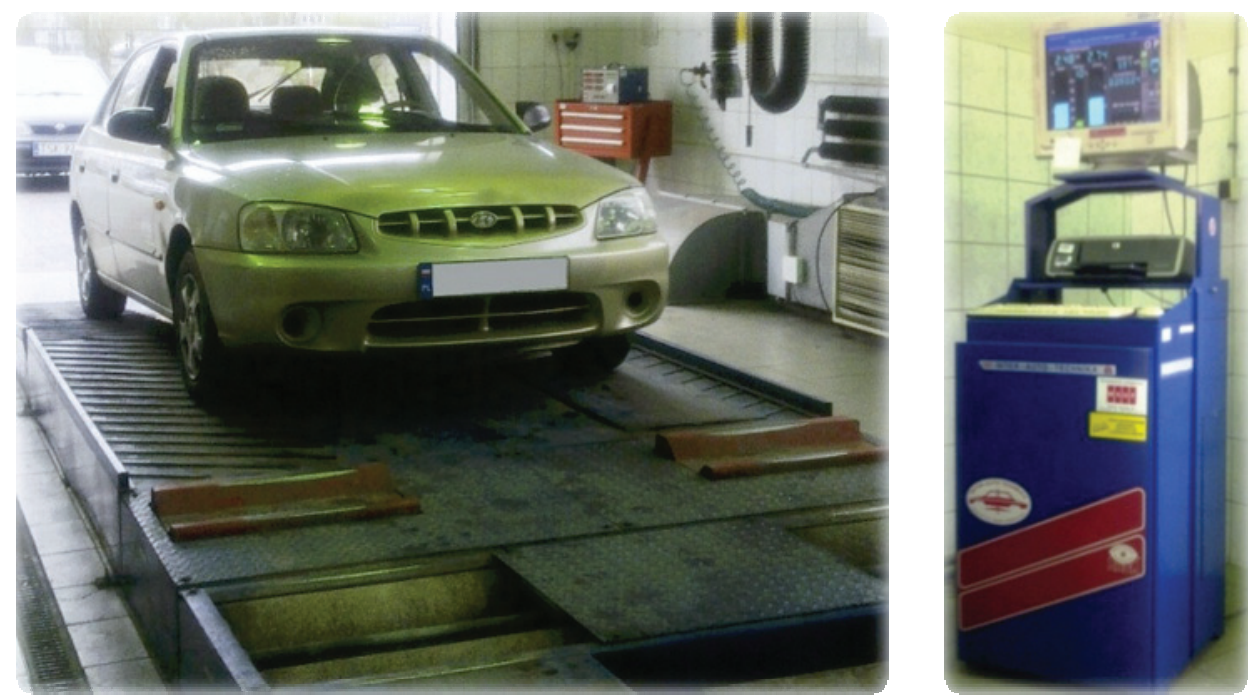

Fig. 1. Diagnostic stand with being tested Hyundai Accent II

\subsection{Testing methodology}

Testing program covered the following:

1. Measurement of front axle braking force $\mathrm{FhP}_{\mathrm{hP}}$, for:

- tyre pressure: $\mathrm{p}_{\mathrm{k}}=0.17 \mathrm{MPa} ; 0.19 \mathrm{MPa} ; 0.21 \mathrm{MPa} ; 0.23 \mathrm{MPa}$,

- load: one person (driver); three persons (driver +2 passengers); five persons (driver +4 passengers).

2. Measurement of braking efficiency index WSH, at rated tyre pressure and one person (driver) load, for the following braking system condition:

a. Worn brake shoes friction lining (appr. 60\%, friction lining thickness $~ 3.5 \mathrm{~mm}$ ); worn tyre tread (appr. 70\%, tread height $\sim 1.5 \mathrm{~mm}$ to TWI (Tread Wear Index); breaking discs and breaking shoes surface without traces of fouling,

b. Worn brake shoes friction lining (appr. 60\%, friction lining thickness $\sim 3.5 \mathrm{~mm}$ ); worn tyre tread (appr. 70\%, tread height $\sim 1.5 \mathrm{~mm}$ to TWI (Tread Wear Index); breaking discs and breaking shoes surface covered (spilled) with water,

c. Worn brake shoes friction lining (appr. 60\%, friction lining thickness $\sim 3.5 \mathrm{~mm}$ ); worn tyre tread (appr. 70\%, tread height $\sim 1.5 \mathrm{~mm}$ to TWI (Tread Wear Index); breaking discs and breaking shoes surface covered (spilled) with oil, 
d. New brake shoes friction lining (thickness friction lining thickness $\sim 8 \mathrm{~mm}$ ); new tyres (tread height $\sim 8 \mathrm{~mm}$ to TWI); breaking discs and breaking shoes surface without traces of fouling; Diagnostic testing was conducted on MAHA roller stand EUROSYSTEM 2000 type in Military Technology University.

First stage covered the following:

a) checking the condition of car suspension system on stand equipped with play (clearance) detector (also called shredder),

b) organoleptic evaluation of braking system elements together with measurement of brake pedal play and its clearance from the bottom of the car.

Brake pedal play checking was performed according to owner's manual of the car with engine off. It is found that measured brake pedal play $\mathrm{S}_{\mathrm{J}}=4 \mathrm{~mm}$ and was in allowed range $\mathrm{S}_{\text {Jdop }}=3-8 \mathrm{~mm}$ imposed by car manufacturer (Fig. 2).

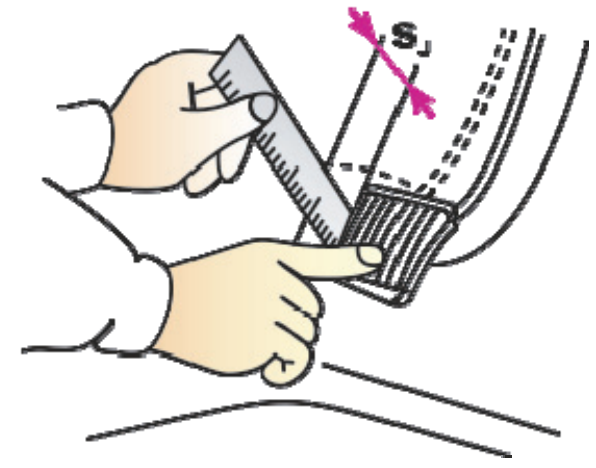

Fig. 2. Brake pedal play measurement [3]

Brake pedal reserve stroke checking was performed after engine starting. For tested car, the stroke $\mathrm{S}_{\mathrm{R}}$ was $75 \mathrm{~mm}$, and, according to manual, it should be lower than $70 \mathrm{~mm}$ (Fig. 3).

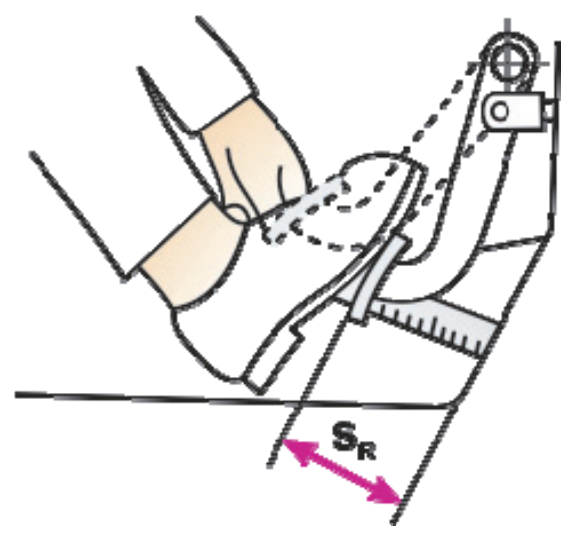

Fig. 3 Brake pedal reserve stroke measurement [3]

Positive results of checking were basis for performing the second stage of testing.

The second stage was basic testing, performed according to especially developed method.

\subsection{Test results analysis}

Partial test results (regarding braking system) are displayed in Tab. 1 and 2, and in Fig. 4-7. According to characteristics displayed in Fig. 4 we can see that tyre pressure increase (at fixed load) results in braking force FhP decrease. Pressure increase of 0.17-0.23 MPa resulted in braking force decrease of $7 \%$ for one-person load, $8.5 \%$ for three-person load, and $12 \%$ for fiveperson load. The load increase causes breaking force $\mathrm{Fhp}_{\mathrm{hP}}$ increase, especially in the extent of low pressures (below the rated pressure). Fully loaded car needs higher force to brake than the one only with a driver. The increase at pressure of $0.17 \mathrm{MPa}$ is nearly $8 \%$. 
M. Kowalski

Tab. 1. Front axle braking force FhP in relation to pressure in tyres and load

\begin{tabular}{|c|c|c|c|c|}
\hline \multirow{2}{*}{$\begin{array}{c}\text { Load } \\
\text { persons }\end{array}$} & \multirow{2}{*}{$\begin{array}{c}\text { Tyre pressure } \mathrm{p} \\
{[\mathrm{MPa}]}\end{array}$} & \multicolumn{3}{|c|}{ Braking force $\mathrm{F}_{\mathrm{h}}[\mathrm{kN}]$} \\
\cline { 3 - 5 } & & & & \\
& & Left side & Right side & \multirow{2}{*}{ Differ. } \\
\cline { 3 - 5 } & & & & $1 \%$ \\
\hline 1 & 0.17 & 2.38 & 2.35 & $2 \%$ \\
\hline 3 & 0.17 & 2.46 & 2.51 & $4 \%$ \\
\hline 5 & 0.17 & 2.58 & 2.69 & $2 \%$ \\
\hline 1 & 0.19 & 2.35 & 2.49 & $3 \%$ \\
\hline 3 & 0.19 & 2.43 & 2.56 & $2 \%$ \\
\hline 5 & 0.19 & 2.48 & 2.29 & $6 \%$ \\
\hline 1 & 0.21 & 2.33 & 2.46 & $3 \%$ \\
\hline 3 & 0.21 & 2.35 & 2.51 & $4 \%$ \\
\hline 5 & 0.21 & 2.36 & 2.28 & $5 \%$ \\
\hline 1 & 0.23 & 2.21 & 2.35 & \\
\hline 3 & 0.23 & 2.25 & 2.38 & \\
\hline 5 & 0.23 & 2.26 & & \\
\hline & & & & \\
\hline
\end{tabular}

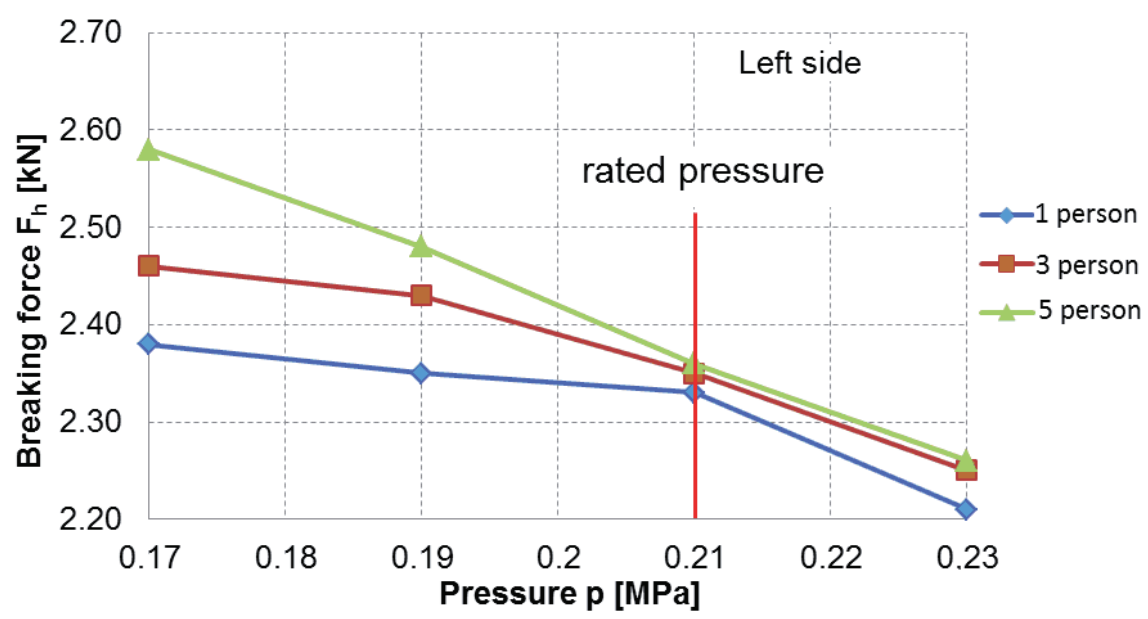

Fig. 4. Braking force change versus pressure in left (road side) wheel for different load

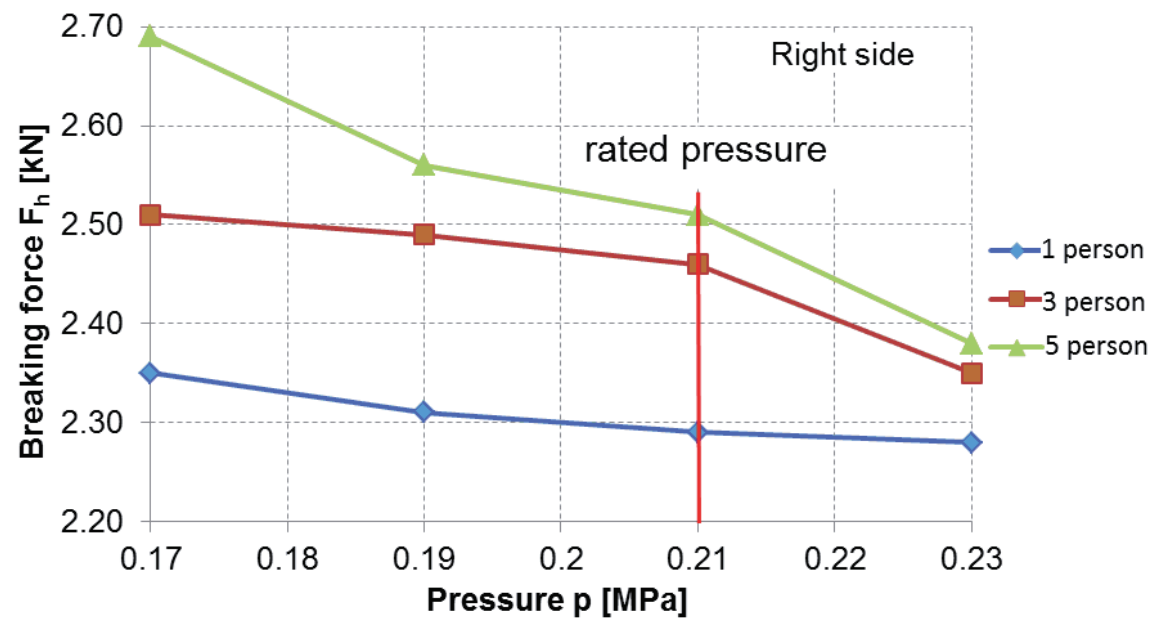

Fig. 5. Braking force change versus pressure in right (curbside) wheel for different load 
The course of breaking force $\mathrm{F}_{\mathrm{hP}}$ in relation to pressure and load was similar in case of right side of forward axle (right wheel - Fig. 5). Pressure increase of 0.17-0.23 MPa resulted in braking force decrease of 3\% for one-person load, $6 \%$ for three-person load, and $11.5 \%$ for five-person load. Fully loaded car needs higher force to brake than the one only with a driver. The increase at pressure of $0.17 \mathrm{MPa}$ is nearly $13 \%$. The reason for such differences between left and right wheel could be different condition of braking mechanisms (different wear of braking discs and braking shoes).

Results of testing of effect of modelled technical conditions (A, B, C, D) of braking system on braking efficiency $\mathrm{W}_{\mathrm{SH}}$ value are displayed in Tab. 2 and fig. 6 and 7.

A. Brake shoes friction lining worn (appr. 60\%, friction lining thickness $\sim 3.5 \mathrm{~mm}$ ); tyre tread worn (appr. 70\%, tread height $\sim 1.5 \mathrm{~mm}$ to tread wear index (TWI); break discs and shoes surface without traces of fouling,

B. Brake shoes friction lining worn (appr. 60\%, friction lining thickness $\sim 3.5 \mathrm{~mm}$ ); worn tyre tread (appr. 70\%, tread height $\sim 1.5 \mathrm{~mm}$ to TWI (Tread Wear Index); breaking discs and breaking shoes surface covered (spilled) with water,

C. Brake shoes friction lining worn (appr. 60\%, friction lining thickness $\sim 3.5 \mathrm{~mm}$ ); tyre tread worn (appr. $70 \%$, tread height $\sim 1.5 \mathrm{~mm}$ to tread wear index TWI); surface of breaking discs and shoes covered (contaminated) with oil,

D. Braking shoes friction lining new (friction lining thickness $\sim 8 \mathrm{~mm}$ ); tyre tread new (tread height $\sim 8 \mathrm{~mm}$ to TWI); break discs and shoes surface without traces of fouling.

Tab. 2. Test results for effect of braking system condition on car performance for one-person load (driver) and at rated tyre pressure

\begin{tabular}{|c|c|c|c|c|c|c|}
\hline \multicolumn{7}{|c|}{ Brakes } \\
\hline \multirow{2}{*}{ Condition } & \multirow{2}{*}{ Axle } & \multicolumn{3}{|c|}{ Braking force $\mathrm{F}_{\mathrm{h}}[\mathrm{kN}]$} & \multirow{2}{*}{$\begin{array}{l}\mathrm{W}_{\mathrm{SH}} \\
{[\%]}\end{array}$} & \multirow{2}{*}{$\begin{array}{c}\text { Braking } \\
\text { force }[\mathrm{kN}\end{array}$} \\
\hline & & left & right & difference & & \\
\hline \multirow[t]{3}{*}{$\mathbf{A}$} & \multicolumn{6}{|c|}{ Braking system without contamination, tyre tread worn } \\
\hline & front & 2.38 & 2.45 & $2 \%$ & $49 \%$ & 7.80 \\
\hline & rear & 1.55 & 1.42 & $13 \%$ & & \\
\hline \multirow[t]{3}{*}{$\mathbf{B}$} & \multicolumn{6}{|c|}{ Braking system (discs and brake shoes) covered with water, tyre tread worn } \\
\hline & front & 2.32 & 2.15 & $8 \%$ & $48 \%$ & 7.44 \\
\hline & rear & 1.55 & 1.42 & $13 \%$ & & \\
\hline \multirow[t]{3}{*}{$\mathbf{C}$} & \multicolumn{6}{|c|}{ Braking system (discs and brake shoes) covered with oil, tyre tread worn } \\
\hline & front & 2.16 & 1.95 & $10 \%$ & $46 \%$ & 7.08 \\
\hline & rear & 1.55 & 1.42 & $13 \%$ & & \\
\hline \multirow[t]{3}{*}{$\mathbf{D}$} & \multicolumn{6}{|c|}{ Brake shoes new, tyre tread new } \\
\hline & front & 2.64 & 2.57 & $3 \%$ & $53 \%$ & 8.18 \\
\hline & rear & 1.55 & 1.42 & $13 \%$ & & \\
\hline
\end{tabular}

According to data displayed in Fig. 4 and 5, we can see that every failure of braking and suspension system results in front axle wheels braking force FhP lowering, and, consequently, braking efficiency index $\mathrm{W}_{\mathrm{SH}}$ decrease below permissible level, which is $50 \%$ for car being tested. Failures arising from moistness of brake disc-brake shoes friction couple are particularly adverse. Such failures are very frequent during use. Brake shoes oiling up (condition C) results in braking force $\mathrm{F}_{\mathrm{hP}}$ of front axle wheels. In case of right, (curb) side wheel, $\mathrm{FhP}_{\mathrm{hP}}$ decreases from $2.45 \mathrm{kN}$ to $1.95 \mathrm{kN}$ (over 20\%). This is clearly reflected as $\mathrm{W}_{\mathrm{SH}}$ index decrease from $49 \%$ to $46 \%$. 


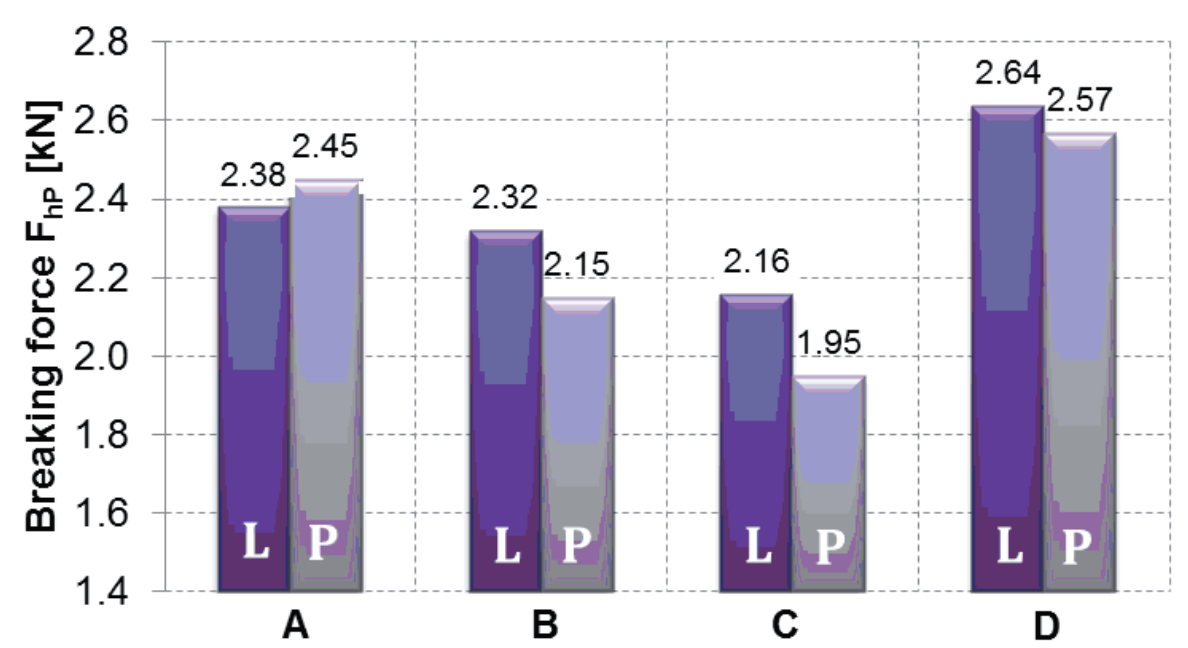

Fig. 6. Braking force Fhp for different condition of braking and suspension system

A. Brake shoes friction lining worn; tyre tread worn, break discs and shoes surface without traces of fouling,

B. Brake shoes friction lining worn, worn tyre tread, breaking discs and breaking shoes surface covered (spilled) with water,

C. Brake shoes friction lining worn, tyre tread worn, surface of breaking discs and shoes covered (contaminated) with oil,

D. Braking shoes friction lining new, break discs and shoes surface without traces of fouling.

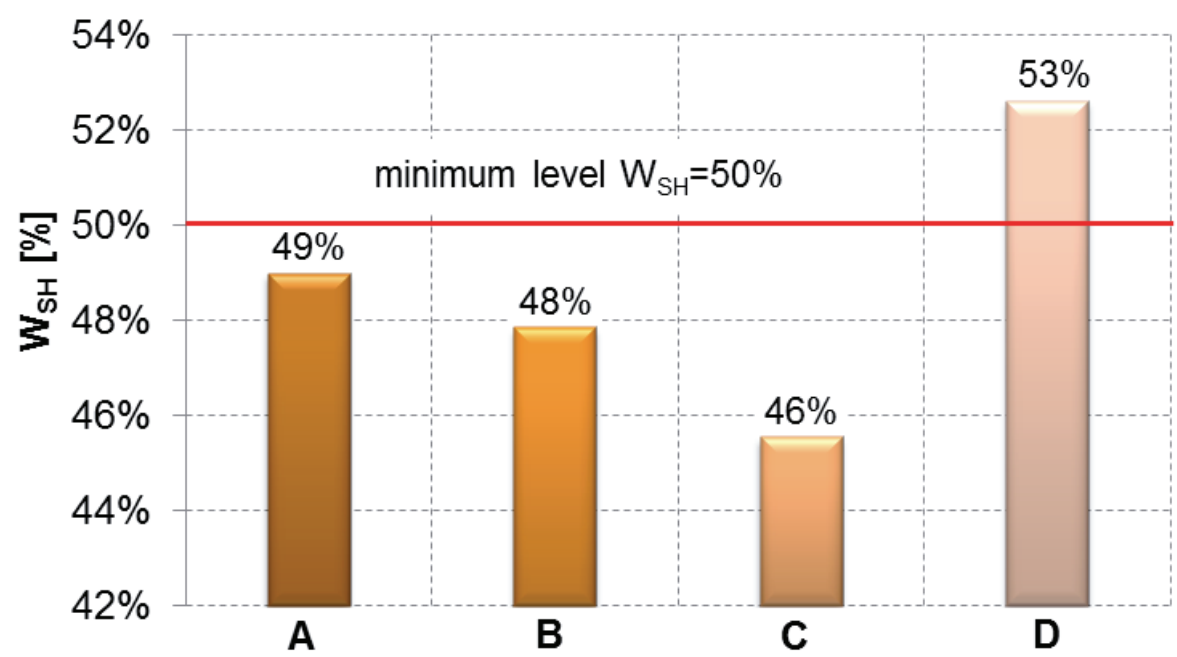

Fig. 7 Braking efficiency index WSH for different condition of braking and suspension system

A. Brake shoes friction lining worn; tyre tread worn, break discs and shoes surface without traces of fouling,

B. Brake shoes friction lining worn, worn tyre tread, breaking discs and breaking shoes surface covered (spilled) with water,

C. Brake shoes friction lining worn, tyre tread worn, surface of breaking discs and shoes covered (contaminated) with oil,

D. Braking shoes friction lining new, break discs and shoes surface without traces of fouling.

Basing on the test results it is found that excessive wear of tyres and brake shoes wear could be the reason of significant $\mathrm{W}_{\mathrm{SH}}$ index decrease resulting in faulty car.

Replacing such elements significantly improves braking efficiency index $\mathrm{W}_{\mathrm{SH}}$ from $49 \%$ to $53 \%$. 


\section{Summary}

Basing on obtained results it is possible to say explicitly that increase of load of Hyundai Accent II car results in braking force increase, because the higher level of this parameter is needed to stop the car.

The effect of tyre pressure increase on braking force change is significantly lower. Moreover, it was observed that braking force decreased together with tyre pressure for front axle.

Excessive wear of tyres, brake shoes and elements under friction (brake discs and shoes) results in decrease of braking efficiency index $\mathrm{W}_{\mathrm{SH}}$, and significant braking distance extending.

Use of new brake shoes and new tyres caused significant improve of braking efficiency index $\mathrm{W}_{\text {SH }}$ (up to appr. 53\%). This confirms the theory that moment of friction in braking mechanisms depends on friction factor $\mu$ and friction couples' interaction. Break shoes wear and contamination (fouling) effect on breaking index $\mathrm{W}_{\mathrm{SH}}$ level.

The testing revealed that tyre pressure and load caused braking efficiency index $W_{H}$ change. This proves the operation instructions on maintaining by the user the relevant tyre pressure (according to current car load) and technical condition of friction couples of braking system.

Friction couples of braking system changes together with brake shoes wear and due to contamination (e.g. oiling up). This can be visible through lower than allowable level of braking efficiency index $\mathrm{W}_{\mathrm{SH}}$, which is the basic legal diagnostic parameter of break system condition assessment.

\section{References}

[1] Dziubak, T., The technical operation of the brake system of motor vehicles, Military University of Technology, Warsaw 2012.

[2] Hebda, M., Niziński, S., Pelc, H., Fundamentals of motor vehicle diagnostics, WKi屯 Warsaw 1980.

[3] Hyundai, User manual Accent, Hyundai Motor Company, 1999.

[4] Merkisz, J., Mazurek, S., On-board diagnostic OBD vehicles, WKiŁ Warsaw 2007.

[5] Regulation of the Minister of Interior and Administration of 23 February 2009 on roadworthiness tests for vehicles of the Polish Armed Forces, Police and other vehicles used in a special way.

[6] Regulation of the Minister of Transport of 2 November 2006 on the certificate confirming compliance with the relevant requirements of vehicle safety or the entry into service.

[7] Trzeciak, K., Diagnosis cars, WKiŁ Warsaw 2008.

[8] Act of June 20, 1997 Law on Road Traffic, Dz. U. z 1997 r. Nr 98, poz. 602. 
